\title{
INCREASING THE POTENTIAL REGION ATTRACTIVENESS IN THE DEVELOPMENT ORDER INVESTATION
}

\author{
Winna Roswinna \\ Winaya Mukti University. Bandung. Indonesia \\ Email: winnaroswina71@gmail.com
}

\begin{abstract}
The purpose of this study is to examine the marketing of regional potentials that will improve the regional economy so that the Regional Government can reduce its dependence on financial assistance from the central government and gradually become a self-sufficient regional government. The methods use descriptive and explanatory survey with sample 200 respondents through simple random sampling, because homogeny respondents. The research result is creativity also involves marketing regional potential products and creating a comparative advantage for the region to attract investors. Creativity also concerns the ability of local governments to be able to attract Special Allocation Funds from the central government so that the central government does not hesitate to provide support in implementing development programs both social development programs and economic development programs as a product of marketing the potential of the region to be able to generate profits and benefits in order the implementation of regional autonomy for the welfare of the people in the region in a sustainable manner. The findings in this study are the physical infrastructure and human resources owned by the regions are elements that investors consider to invest.
\end{abstract}

Keywords: marketing; regional potential; investor decisions; investment

\section{MEMBANGUN DAYA TARIK KEUNGGULAN DAERAH DALAM RANGKA MENINGKATKAN INVESTASI}

\begin{abstract}
ABSTRAK. Tujuan penelitian ini adalah untuk mengkaji potensi pemasaran daerah dalam rangka peningkatan perekonomian daerah sehingga pemerintah daerah dapat mengurangi ketergantungannya pada bantuan keuangan dari pemerintah pusat dan secara bertahap menjadi pemerintah daerah yang mandiri. Metode penelitian yang digunakan adalah metode survey deskriptif dan eksplanatori dengan 200 responden melalui pemilihan sampel acak sederhana, karena responden homogen. Berdasarkan hasil penelitian ditemukan bahwa kreativitas berkaitan dengan kemampuan pemerintah daerah untuk dapat mencairkan Dana Alokasi Khusus dari pemerintah pusat sehingga pemerintah pusat tidak segan-segan memberikan dukungan dalam pelaksanaan program pembangunan baik. program pembangunan sosial dan program pembangunan ekonomi sebagai produk pemasaran potensi daerah agar dapat menghasilkan keuntungan dan manfaat dalam rangka penyelenggaraan otonomi daerah untuk kesejahteraan masyarakat di daerah secara berkelanjutan. Temuan dari studi ini adalah bahwa infrastruktur fisik / infrastruktur dan sumber daya manusia yang dimiliki oleh daerah merupakan elemen yang menjadi pertimbangan investor untuk berinvestasi.
\end{abstract}

Kata kunci: pemasaran; keunggulan daerah; keputusan investor; investasi

\section{INTRODUCTION}

Regional economic development by marketing regional potential can be implemented if the local government implements "good governance" so that it can suppress and avoid the term "expensive economic costs" that is the amount of expenditure that does not need to be issued as a result of local government officials who do not understand efficiency in investment implementation as an effort to utilize the regional potential. In this case, the activities carried out by the Regional Government are analyzing opportunities and making strategic steps in marketing regional products and looking for investors to be able to obtain optimal results in utilizing regional potentials, regional development programs, and regional development priority scales by using strategic marketing and marketing mix to get consumers and investors both locally (Potts, Thomas, \& Nichols, 2003).

Development in the regions is a socially charged condition, where the budget used for development is less able to create revenue to be able to carry out sustainable development. For this reason, an analysis of the marketing potential of the regional potential is needed by determining the superior potential to be made into a priority area scale so that investors who will invest in their regions have clear direction and goals and have promising investment prospects. In carrying out marketing of regional potential, the Regional Government can create a short, medium, and long-term program of development that is targeted, comprehensive, and sustainable by inviting third parties as partners in utilizing regional potentials in a joint operation, joint venture (Wang \& Yang, 2008)

In general, economic activity in Indonesia is reflected in the Gross Regional Domestic Product (PDRB). According to (Said \& Ali, 2016), "Gross Regional Domestic Product is the basis for measuring the added value that grows from the types of economic activities in the region". In increasing regional competitiveness, an economic sector is needed which is the basis for the region to increase people's income.

To accelerate regional economic development in order to improve people's welfare and regional competitiveness, economic development can be developed through the development of potential economic sectors that become regional leaders. In general, the regional economic potential that is favored is the sector which is the 
leading commodity experiencing the highest development so that it makes a large contribution to GRDP and increases Regional Original Income (P AD). Analysis of leading economic potential is very important in development planning and development implementation both at the local and regional levels. Development based on superior economic potential can also be utilized to support local competitiveness and support the largest economy in the area (Jan, Burck. Franziska, Marten. Christoph, 2007).

According to (Hanselll al, 2016) "Development is a transformation in terms of structural change, namely: changes in the economic structure of society including changes in the balance of conditions inherent in basic economic activities and forms of economic structures". Human resources are the main factor influencing economic development, which is also supported by natural resources, science and technology, and the existing production capacity in the area.

Economic development in a limited definition is the increase in production and income that can occur without actual development (Abad et al., 2017). The production in question is a product of an area that has economic value which can later be sold for regional income. On the other hand, economic development in a broad definition must include growth (such as the main characteristics of the development process) (Cabiddu, Lui, \& Piccoli, 2013). This can be seen from the increasing level of citizen growth and the need for more development to provide services to the community.

From the existing income, there is a correlation between PAD and sectors that grow in a region. According to Rani, "most of AD is dependent on regional economic growth(PDRB) as seen from the total investment in an area" (Rani, 2015). Then Rani explained, "Because PAD is very dependent on the extent to which regions can encourage economic growth (PDRB). If the GRDP increases, this shows that it can encourage PAD to increase. It is believed there is a correlation between economic growth. (GRDP) and local income from taxes and fees "(Pirard, 2012).

In business activities, marketing is a function that directly determines the company's objectives (corporate objectives) and activities that have a broad scope, because in addition to internal and external companies. As stated by (Kotler \& Armstrong, 2018) that "marketing is a social and managerial process in which individuals or groups aim to fulfill their needs and desires through creativity, offering, and exchanging product values with others". The most basic marketing concept is how the company can meet customer needs (customer requirements).

In maintaining business continuity, every good company, such as the government in utilizing the potential of the region must always strive to have Competitive Advantage (excellence in certain fields to win the competition), which in this case can be in the form of excellence in the service marketing mix program to consumers. Likewise, the regional government in utilizing the potential of the region which includes tourism, industry, and education which is very attentive to the interests and trust of the community, implements a program to improve the marketing mix of regional potential with the ultimate goal of encouraging investors to make decisions in choosing to invest in the region (Jan, Burck, Franziska, Marten, Christoph, 2007).

The concept of regional potential marketing mix is basically the same as the concept of service marketing mix. Where in both cases, marketers must be able to choose and analyze the target market. So that the formulation of the regional potential marketing mix carried out by the regional government refers to the target market (investors). In the marketing mix, the potential areas of using 4P (Products, Prices, Places, and Promotions) are inadequate, because regional potential characteristics contain service characteristics that have intangible elements, cannot be separated, variability (variability), easily damaged (Easily vanished) ( Teo et al., 2010).

It must be stated that "the service marketing mix is a marketing tool consisting of seven elements, namely products(services), prices, places, promotions, participants, physical evidence, and processes that all variables can be controlled and manipulated by an organization to achieve an organization's competitive advantage. those involved in service use the service marketing mix to assist their strategy in achieving high customer / customer value which ultimately determines the competitive position in the target market "(Martin, Javalgi, \& Cavusgil, 2017).

The seven elements of the service marketing mix mentioned above can be described as follows:

Products (Products); are physical goods, services, or a combination of both, which are offered to the target market. Products are the first marketing mix element that we need to know, to be able to arrange the next marketing mix that is appropriate for the type of product (Abad et al., 2017).

Price / cost is the amount of money that a customer must spend to get a company's product. In considering prices, consideration must be given to the level of product demand, estimated production costs, competitor product prices, competitive situation, and market conditions and targets (Hayati \& Purnama, 2016).

Place (Place); is to plan and implement a product distribution program through the right service location, so that the product is in the right place, at the right time with the right amount according to the needs and desires of consumers. Manufacturing products are defined as distribution channels (zero channels, two-level channels, and multilevel channels) while place products for industrial services are defined as location services / service locations used to supply services to targeted customers is the main decision. The decision regarding which service location to use involves considering how services are provided to customers and where they will occur (Keh, Nguyen, \& $\mathrm{Ng}, 2007)$. 
Promotion (Promotion); is a combination of advertising variables, face-to-face sales, sales promotion, and publicity carried out by companies to inform products to customers (consumers), so that customers (consumers) are motivated / motivated to make purchases (Hayati \& Purnama, 2016).

People; are the people who are directly involved in carrying out all company activities, and are a factor that plays an important role for all organizations. In service companies, this person element not only plays an important role in production or operations but also in making direct contact with consumers. The behavior of the people who are directly involved is very important in influencing the quality of services offered and the image of the service company concerned (Ryschka, Murawski, \& Bick, 2016).

Physical Facilities (Physical Evidence); is a problem that significantly affects the consumer's decision to buy and use the service product offered. The elements included in physical evidence include, among others, the physical environment, in this case the physical building, furniture / equipment, fixtures, logos, colors and other items that are combined with the services provided such as tickets, covers, labels, etc. In addition, a supportive corporate atmosphere such as visuals, aroma, sound, layout, etc. (Buhalis \& Foerste, 2015).

Process; means company business, in carrying out and carrying out its activities to meet the needs and desires of its consumers. For service companies, collaboration between marketing and operations is very important in this element of the process, especially in serving all the needs and desires of customers (consumers) quickly and precisely (Cabiddu et al., 2013).

(Kotler \& Armstrong, 2018), argues that the buyer's decision which includes product choice, brand choice, dealer choice, time of purchase, and number of purchases is influenced by marketing mix stimuli and environmental stimuli (other stimuli)) through buyer and buyer characteristics. decision making process.

(Handayani Sri, Fariyanti Anna, 2016) stated that consumer decision making is the process of making consumer decisions about a product or service consisting of (need recognition, pre-purchase search, and alternative evaluation) which is influenced by the psychological field (motivation, perception, learning). , personality, and attitude) as internal influences, as well as experiences, while external influences are input from the consumer decision-making process which consists of the company's marketing efforts (products, promotions, prices, and distribution) and socio-culture. environment (family, informal sources, other non-commercial sources, social class, and subcultures and cultures). The result of the consumer decision-making process is post-purchase behavior which consists of evaluation of purchases (trials, repeat purchases) and post purchases. Based on the information above, it is clear that the service marketing mix is to encourage consumers to make decisions at the time of the initial purchase (before purchase), purchase (at the time of purchase), and post-purchase (after purchase). in addition to the influence of other external and internal consumer factors.

\section{METHOD}

The method used is descriptive and explanatory survey with a sample of 200 respondents through simple random sampling, because the respondents are homogeneous. Descriptive research is research that aims to obtain an overview of the characteristics of the variables (regional potential marketing mix). The nature of verification research wants to test the truth of a hypothesis by collecting data in the field. Where in this research will be tested whether the regional potential marketing mix influences investment selection decisions. Given the nature of this research is descriptive and verification is carried out through data collection in the field, the research methods used are descriptive survey methods and explanatory survey methods. This type of research is causality because it will examine the causal relationship between independent and non-independent variables. The unit of analysis in this study is an individual because only investors in Indonesia are the respondents. The time horizon in this study is cross-sectional because information from a portion of the population (sample of respondents) is collected directly on the scene empirically, to determine the opinion of several populations on the object under study. The analytical method to test the hypothesis is path analysis.

\section{RESULTS AND DISCUSSION}

Discussion of the results of this study includes an analysis of seven regional marketing mix variables, namely product, price, location, promotion, human resources, physical facilities, and service processes as Independent variables, to Investor Decisions as the dependent variable. The results of interviews with as many as 200 investors in Indonesia, both direct interviews and / or fill in the questionnaire forms that serve as respondents. Then get the results of the correlation of each sub-variable marketing potential regional mix as follows:

Table 1. Correlation Matrix

\begin{tabular}{cccccccc}
\hline & $\mathbf{X 1}$ & $\mathbf{X 2}$ & $\mathbf{X 3}$ & $\mathbf{X 4}$ & $\mathbf{X 5}$ & $\mathbf{X 6}$ & $\mathbf{X 7}$ \\
\hline $\mathbf{X 1}$ & 1 & 0.402 & 0.428 & 0.446 & 0.654 & 0.689 & 0.486 \\
$\mathbf{X 2}$ & 0.402 & 1 & 0.407 & 0.400 & 0.443 & 0842 & 0.430 \\
$\mathbf{X 3}$ & 0.428 & 0.407 & 1 & 0.517 & 0.411 & 0.565 & 0889 \\
$\mathbf{X 4}$ & 0.446 & 0.400 & 0.517 & 1 & 0.496 & 0.548 & 0702 \\
$\mathbf{X 5}$ & 0.654 & 0.443 & 0.411 & 0.496 & 1 & 0.606 & 0.475 \\
$\mathbf{X 6}$ & 0.689 & 0842 & 0.565 & 0.548 & 0.606 & 1 & 0.609 \\
$\mathbf{X 7}$ & 0.486 & 0.430 & 0889 & 0702 & 0.475 & 0.609 & 1 \\
\hline
\end{tabular}


Table 1 explain that the regional potential marketing mix variable jointly influences the Investor's decision to invest is $18.9 \%$ and the remaining $81.1 \%$ is influenced by other factors not included in the study.

Based on the theoretical framework that there is an influence between the regional potential marketing mix on the Investor Decision, the next hypothesis will be tested in the following form:

$\mathrm{Ho}=\rho \mathrm{yx} 1=\rho \mathrm{yx} 2=\ldots=\rho \mathrm{yx} 7=0$

$\mathrm{H} 1=$ At least there is $\rho y x i \neq 0$

The test statistics used are: 26,447

from the F-value distribution table obtained

$\mathrm{F} \alpha ; \mathrm{k}(\mathrm{nk}-1)=\mathrm{F} 0.05 ; 7 ; 803=2.103$

Because $F>F \alpha$; $k$ (nk-1), then Ho is rejected, meaning it can be continued on individual testing with the following hypothesis:

$\begin{array}{ll}\text { Ho } & : \rho_{x i x j} \leq 0 \\ \text { H1 } & : \rho_{x i x j}>0\end{array}$

Then obtained the path coefficient and testing as follows

$\mathrm{t}\left(1-_{\alpha) ;(\mathrm{nk}-1)}=\mathrm{t} 0.95 ; 95=1.6608\right.$

Then obtained the path coefficient along with testing as follows:

Table 2. Path coefficients X1, X2, X3, X4, X5, X6, and X7, Against $Y$

\begin{tabular}{|c|c|c|c|c|}
\hline Coefficient & Pathway & T-test & t table & Conclusion \\
\hline Pyx1 & 0.288 & 5,359 & 1.6608 & $\begin{array}{l}\text { Ho Rejected, there is } \\
\text { a significant effect }\end{array}$ \\
\hline Pyx2 & 0.342 & 5,051 & 1.6608 & $\begin{array}{l}\text { Ho Rejected, there is } \\
\text { a significant effect }\end{array}$ \\
\hline Pyx3 & 0.120 & 2,520 & 1.6608 & $\begin{array}{l}\text { Ho Rejected, there is } \\
\text { a significant effect }\end{array}$ \\
\hline Pyx4 & 0.076 & 1,497 & 1.6608 & $\begin{array}{l}\text { Ho Accepted, there } \\
\text { was no significant } \\
\text { effect }\end{array}$ \\
\hline Pyx 5 & .347 & 7,380 & 1.6608 & $\begin{array}{l}\text { Ho Rejected, there is } \\
\text { a significant effect }\end{array}$ \\
\hline Pyx6 & 0.730 & 8,000 & 1.6608 & $\begin{array}{l}\text { Ho Rejected, there is } \\
\text { a significant effect }\end{array}$ \\
\hline Pyx 7 & .141 & 1,491 & 1.6608 & $\begin{array}{l}\text { Ho Rejected, there is } \\
\text { a significant effect }\end{array}$ \\
\hline
\end{tabular}

Based on table 2 above, the results of processing, in general, the regional potential marketing mix affects Investor Decisions, this is with the statement (Alyas, 2017), that the service marketing mix is a marketing tool consisting of seven elements, namely products (services), prices, venue, promotion, participants, physical evidence, and the process of all variables can be controlled and managed by the organization to achieve competitive advantage in increasing customer interest. Organizations involved in services use the service marketing mix to assist their strategies in achieving customer satisfaction which ultimately determines their competitive position in the target market and their company image (Hidayat \& Firdaus, 2014; Kanaidi, 2010; Nguyen, 2013; Rahyuda \& Atmaja, 2018 ).
When viewed from each element of the regional potential marketing mix, it turns out that physical infrastructure has a dominant influence. Investor Decision of 0.730 and followed by human resources of 0.347 , this shows that the elements that must be considered to increase investor interest in investing in the region are the completeness of physical infrastructure / infrastructure in the area and the ability of human resources owned by the region.

(Grégoire, Salle, \& Tripp, 2015; Murphy, Benckendorff, \& Moscardo, 2007), states that the people in this service are those who are directly involved in carrying out all company activities and are factors that play an important role for all organization. In service companies, this person element not only plays an important role in the field of production or operation but also in making direct contact relationships with consumers. Because people form the service and at the same time hand it over to consumers. The behavior of the people directly involved is very important in influencing the quality of services offered and the image of the service company concerned (Eisenberger \& Stinglhamber, 2011; Haverila \& Fehr, 2016, 2016; Lemmetyinen, Dimitrovski, Nieminen, \& Pohjola, 2016).

Based on the results of the statistical analysis above, it can be seen that the contribution of human resources and physical infrastructure/ regional infrastructure to the Investor Decision. (Tynan, McKechnie, \& Chhuon, 2010) quoted from the link in the profit-service chain, that the better quality of local government internal services is demonstrated by employee satisfaction, employee loyalty, employee productivity, and employee capability, and integrated with infrastructure/ infrastructure owned, the higher the interest of investors to invest. This provides input to the Regional Government to always pay attention to the ability of its human resources (staff employees and administrative officials), both in terms of skills, as well as speed and accuracy in serving investors (Agussalim, Limakrisna, \& Ali, 2017; Kropp, Lindsay, \& Shoham, 2008; Meyskens \& Bird, 2015; O’Reilly, 2009).

This physical evidence is a problem that significantly influences an investor's decision to invest. The elements included in physical evidence include the physical environment, in this case, physical buildings, road infrastructure, equipment, equipment, logos, colors and other items integrated with the services provided such as tickets, covers, labels, etc. so. In addition, the atmosphere of local government offices that support such as visuals, aroma, sound, spatial planning, and others. In the service industry managing physical evidence is an important strategy in marketing services, by trying to use tangible elements, to strengthen the meaning of intangible core values (Mattera, Baena, \& Cerviño, 2012).

The findings in this study are the physical infrastructure and human resources owned by the region are elements that investors consider to invest. The attractiveness of regional 
potentials in general in districts / cities in Indonesia is the potential of the uniqueness of the region owned, the cost of utilizing the potential of training is lower, the location is more natural, but it has not been communicated optimally, the infrastructure that must be developed, human resources are easier to train, and investment processes / procedures that are still too bureaucratic.

Investors' decision to invest apparently only has an interest in two dominant elements, namely if the infrastructure owned by the region is adequate and the regional human resources that are reliable, can work and can maintain the security situation.

The elements of the regional potential Marketing Mix which include product potential, potential cost, potential location, human resource potential, physical infrastructure potential, and process potential together influence an Investor's decision to invest, but promotion does not significantly influence investor decision making.

Physical infrastructure and human resources owned by the region are elements considered by investors to invest. Research findings developing preliminary research from (Abad et al., 2017) are physical goods, services, or a combination of both, which are offered to target markets. Products are the first marketing mix element that we need to know, to be able to arrange the next marketing mix that is appropriate for the type of product. (Hayati \& Purnama, 2016) price / cost is the amount of money that a customer must spend to get a company's product. In considering prices, consideration must be given to the level of product demand, estimated production costs, competitor product prices, competitive situation, and market conditions and targets.

Also the form of research (Keh et al., 2007) that place (Place); is planning and implementing a product distribution program through the right service location, so that the product is in the right place, at the right time with the right amount according to the needs and desires of consumers. Manufacturing products are defined as distribution channels (zero channels, two-level channels, and multilevel channels) while place products for industrial services are defined as location services / service locations used to supply services to the intended customers are key decisions. Decisions about the location of services to be used involve consideration of how the service is delivered to customers and where it will occur.

Then (Hayati \& Purnama, 2016) explained the promotion (Promotion); is a combination of advertising variables, face-to-face sales, sales promotions, and publicity made by the company to inform the product to customers (consumers), so that customers (consumers) are motivated / motivated to make purchases. (Ryschka et al., 2016) people; are people who are directly involved in carrying out all company activities, and are factors that play an important role for all organizations. In service companies, this person element not only plays an important role in the field of production or operation but also in making direct contact with consumers. The behavior of the people directly involved is very important in influencing the quality of services offered and the image of the service company concerned.

Then (Buhalis \& Foerste, 2015) explains that physical facilities (Physical Evidence); is a problem that significantly influences the consumer's decision to buy and use the product service offered. The elements included in the physical evidence include the physical environment, in this case, physical buildings, furniture/ equipment, equipment, logos, colors and other items combined with the services provided such as tickets, covers, labels, etc. Apart from that the supporting company atmosphere such as visuals, aroma, sound, spatial planning, etc..

\section{CONCLUSION}

The attractiveness of regional potential in general in regencies/cities in Indonesia is the potential of the uniqueness of the region owned, the cost of utilizing the potential of being trained is lower, a more natural location, but not yet optimally communicated, infrastructure that must be developed, more human resources easy to train, and investment processes/procedures that are still too bureaucratic. Investors' decision to invest turns out to have an interest in only two dominant elements, namely if the infrastructure owned by the region is adequate and the regional human resources that can be relied on, that can work and can maintain the security situation. The elements of the regional potential Marketing Mix which include product potential, cost potential, location potential, HR potential, physical infrastructure potential, and process potential together influence the Investor's decision to invest, but promotion no have significant effect on investor decision making. The physical infrastructure and human resources owned by the regions are elements that investors consider to invest.

\section{REFERENCES}

Abad, A., Victoria Fernández-Molina, J., Bikandi, J., Ramírez, A., Margareto, J., Sendino, J. \& Willem, H. (2017). Molecular cloning and transcription regulation of the $\mathrm{xlnD}$ gene Aspergillus nidulans which encodes beta-xylosidase. Annual Review of Phytopathology. 12, 87-98. https://doi. org/10.1016/j.cell.2016.12.020.

Agussalim, M., Limakrisna, N. \& Ali, H. (2017). Mutual Fund Performance: Conventional and Sharia Products. International Journal of Economics and Financial. 13, 121-131.

Alyas, (2017). Small And Medium Business Development Strategies In Strengthening The Community Economy (Case Study of Maros Bread Business in Maros Regency). Sociohumanities. 2(5), 37-49 https://doi.org/10.24198/sosiohumaniora. v19i2.12249. 
Buhalis, D. \& Foerste, M. (2015). SoCoMo's marketing for travel and tourism: Empowering shared value creation. Journal of Destination Marketing and Management. 7(12), 67-79.https://doi. org/10.1016/j.jdmm.2015.04.001.

Cabiddu, F., Lui, T. W., \& Piccoli, G. (2013). Managing Value Co-Creation In The Tourism Industry. Annals of Tourism Research, 42, 86-107. https:// doi.org/10.1016/j.annals.2013.01.001

Eisenberger, R., \& Stinglhamber, F. (2011). Behavior results from perceived organizational support. Within perceived organizational support: Fostering enthusiastic and productive employees 3, (21) 187-210. https://doi.org/10.1037/12318-007.

Grégoire, Y., Salle, A., \& Tripp, T. M. (2015). Managing social media crises with your customers: The good, the bad, and the ugly. Business Horizons, 58, (2), 173-182. https://doi.org/10.1016/j. bushor.2014.11.001.

Handayani, S., Fariyanti, A. \& Nurmalina, R. (2016). Simulation of forecast analysis of beef selfsufficiency in Indonesia. Sociohumanities. Hanselll al. (2016). Creating Value Through Active Portfolio Management: Value Maker Report 2016. BCG. 3, (15), 137-149.

Haverila, M.J. \& Fehr, K. (2016). The effect of product excellence on customer satisfaction in project management. International Journal of Project Management, 34, (4), 570-583. https://doi. org/10.1016/j.ijproman.2016.02.007.

Hayati, N. \& Purnama, R. (2016). The effect of the political marketing mix on voter decisions (a study in the 2014 General Election of the Indonesian People's Representative Council, Electoral District II, West Java). International Journal of Applied Business and Economic Research. 7(3), 33-45.

Hidayat, D.R. \& Firdaus, M. R. (2014). Analysis of the Influence of Service Quality, Price, Trust, Company Image and Customer Satisfaction on Customer Loyalty (Study on Telkom Speedy Customers in Palangka Raya). Journal of Management Insights. $12,(7), 50-62$.

Jan, B., Franziska, M. \& Christoph, B. (2007). Climate Change Performance Index - 2015 Results. Corporate Social Responsibility and Environmental Management. 3, (8), 29-42. https:// doi.org/10.1258/002367778780936313

Kanaidi. (2010). The Influence of Customer Relationships, Company Image, and Customer Trust on Loyalty. Scientific Magazine, 6, (5), 55-67.

Keh, H.T., Nguyen, T.T.M. \& Ng, H.P. (2007). The effect of entrepreneurial orientation and marketing information on SME performance. Journal of Business Venturing, 22, (4), 592-611. https://doi. org/10.1016/j.jbusvent.2006.05.003.

Kotler, P., \&Armstrong, G. (2018). Principles of Marketing (17th Edition). Pearson Education Limited.p.132.

Kropp, F., Lindsay, N.J. \& Shoham, A. (2008). Entrepreneurial orientation and international entrepreneurial business venture startups. International Journal of Entrepreneurial Behavior and Research. 14, (2), 102-117. https://doi. org/10.1108/13552550810863080

Lemmetyinen, A., Dimitrovski, D., Nieminen, L. \& Pohjola, T. (2016). Cruise destination brand awareness as a moderator in the motivationsatisfaction relationship. Tourism Reviews. 5, (6), 77-89. https://doi.org/10.1108/TR-07-2016-0027.

Martin, S.L., Javalgi, R.G. \& Cavusgil, E. (2017). The marketing capabilities, positional excellence, and performance of a born global company: The contingent effect of ambidextrous innovation. International Business Review, 26, (3), 527-543. https://doi.org/10.1016/j.ibusrev.2016.11.006

Mattera, M., Baena, V. \& Cerviño, J. (2012). Analyzing Social Responsibility as a Driver of Corporate Brand Awareness. Procedia-Social and Behavioral Sciences. 5, (9), 47-58. https://doi.org/10.1016/j. sbspro.2012.09.1093.

Meyskens, M., \& Bird, L. (2015). Crowdfunding and value creation. Journal of Entrepreneurship Research, 5, (2), 155-166. https://doi.org/10.1515/ erj-2015-0007

Murphy, L., Benckendorff, P. \& Moscardo, G. (2007). Linking Travel Motivation, Traveler Self-Image and Destination Brand Personality. Journal of Travel \& Tourism Marketing. 6, (4), 12-23. https://doi.org/10.1300/J073v22n02.

Nguyen, N. (2013). The Role of Mediating Customer Trust in Customer Loyalty. Journal of Service Science and Management, 6, (1), 96-109. https:// doi.org/10.4236/jssm.2013.61010.

O'Reilly, N. (2009). Value Creation: The Power of Brand Equity. Journal of Nonprofits \& Public Sector Marketing. 7(2), 112-125. https://doi. org/10.1080/10495140802529144.

Pirard, R. (2012). Market-based instruments for biodiversity and ecosystem services: Lexicon. Environmental Science and Policy. 3, (8), 29-39. https://doi.org/10.1016/j.envsci.2012.02.001.

Potts, A.C., Thomas, A.D. \& Nichols, E. (2003). Economic and social assessment of flying (pelagic) fisheries in Tobago, Trinidad and Tobago. Proceedings 
of the FiftyFourth Annual Gulf and Caribbean Fisheries Institute. 54, (1), 124-132.

Rahyuda, I.K., \& Atmaja, N.P.C.D. (2018). The effect of fairness on prices, corporate image on satisfaction and loyalty of domestic Gia flight users in Denpasar. Journal of Economics and Finance, 15, (3), 370-395.

Rani, F. \& W.C. (2015). Indonesia's Motivation in Applying the Policy Model. Transnational Journal. 2, (7), 27-37.

Ryschka, S., Murawski, M. \& Bick, M. (2016). Location Based Services. Information Systems Business \& Engineering, 58, (3), 233-237.https://doi. org/10.1007/s12599-016-0430-8.

Said, M. \& Ali, H. (2016). An analysis on the factors affecting profitability level of Sharia banking in Indonesia. Banks and Bank Systems, 11, (3), 2836. https://doi.org/10.21511/bbs.11(3).2016.03.
Teo, C., Chui, B., Rahim, F. A., Hassan, F. H., Musa, R. \& Yusof, J. (2010). Exploring Tourist Experiencescape and Servicescape at Taman Negara. National Park. International Journal. 4, (3), 54-67. https://doi.org/http://dx.doi. org/10.7763/IJTEF.2010.V1.5.

Tynan, C., McKechnie, S. \& Chhuon, C. (2010). Cocreating value for luxury brands. Journal of Business Research. 6, (7), 23-39. https://doi. org/10.1016/j.jbusres.2009.10.012.

Wang, X. \& Yang, Z. (2008). Does country-of-origin matter in the relationship between brand personality and purchase intention in emerging economies? Evidence from China's auto industry. International Marketing Review. 7, (4), 211-224 https://doi.org/10.1108/02651330810887495. 